\title{
The Effectiveness Of The Apheresis Method On The Quality Of Trombosit Concentrat At UTD PMI Surabaya
}

\author{
Renata Primasari*, Wahyu Wirahmayati \\ Universitas Dr. Soetomo Surabaya, Indonesia \\ * primasarirenata@gmail.com
}

\begin{abstract}
Apheresis is a new method that is safe in the collection of blood components, easier and more effective than conventional methods. Apheresis is obtained from one donor, donors are connected to a machine that can clean up blood and only take platelets. The remaining cells and blood plasma are then returned to the donor's body. The purpose of this study was to determine the effectiveness of apheresis methods on the quality of blood products in UTD PMI Surabaya. This type of research uses a post test only control design, which was conducted on November 1st, 2019 - March 30th, 2020 with a sample of 50 TC Apheresis and $50 \mathrm{TC}$ conventional. The quality of blood products carried out by the apheresis method at UTD PMI Surabaya has met the quality standards that have been tested. While the quality of blood products that do not use the Apheresis method at UTD PMI Surabaya, there are 2 samples that do not meet the standards, 48 other samples have met the standards.

The Apheresis method is more effective than conventional TC.
\end{abstract}

Keywords: TC Apheresis, TC Conventional, The Quality Of Blood Products in UTD PMI Surabaya 


\section{STRADA Jurnal Ilmiah Kesehatan}

DOI: $10.30994 /$ sjik.v9i2.511

ISSN: 2252-3847 (print); 2614-350X (online)

Vol.9 No.2 November 2020 Page. 1617-1621

\section{BACKGROUND}

Based on WHO standards, the minimum blood requirement in Indonesia is around 5.1 million bags of blood per year ( $2 \%$ of Indonesia's population) while the current production of blood and components is 4.1 million bags out of 3.4 million donations. Of the available blood, $90 \%$ of them come from voluntary blood donors (MOH, 2016).

Blood availability is very dependent on blood donors according to WHO guidelines, so blood needs should be met $100 \%$ from voluntary blood donors. In $2017,91.8 \%$ of the blood came from voluntary donors, some of UTD experienced difficulties in obtaining voluntary donors so that they had to fulfill themselves through substitute donations from families (8\%) paid blood donors (2\%) (MOH RI, 201 Blood transfusion is an important component in the management of patients with injury in cases of accidents, surgical conditions, malignancies, pregnancy complications and anemia.1 Childhood is a condition that mostly requires blood transfusions in low-income countries.

Donor Apheresis is another type of blood donation activity. Apheresis itself has a meaning as an activity of the application of medical technology that carries out the process of taking one of the blood components through a device. This means that the donor only provides one of the other blood components to be returned to the body (F. Sadikah and Robby Nur Aditya: 2016).

Apart from regular blood donation, there is something called Apheresis blood donation. Unlike ordinary donors, Apheresis donors use a special machine to extract platelet blood components. Other blood components that are not needed will return to the body. Doctor David H. Sidabutan M. Biomed explained that the advantages of Apheresis blood donation are that the quality of the blood components taken (platelets) is more consistent and has a larger content. This is beneficial for patients receiving these components. For example, patients who receive these components and blood cancer patients who need additional platelets. (Fahrul Jaya Diputra 2017, Media Indonesia.com).

Apheresis is a new method that is safe for collecting blood components, easier and more effective than conventional methods. In certain blood donations that are collected (such as platelets, plasma or red blood cells) so that components that are not needed are returned to the donor's body. One apheresis platelet donor bag is equivalent to 10 regular platelet donor bags. An apheresis transfusion from a single donor very well reduces the risk of developing the immune system in the transfusion process and also reduces the risk of infection with bacteria because it only receives blood from a single donor whereas the conventional way comes from multiple donors. (Dyah Ayu Lestari: 2014).

Apheresis is different from the previous method, the platelets in apheresis are obtained from one donor. During this procedure, the donor is connected to a machine that can separate the blood and only collect platelets. The remaining cells and blood plasma are then flowed back to the donor's body. Platelet transfusion is a procedure that is rarely performed and requires special consideration from a doctor. Health risks are not spared from patients who undergo it, therefore donors and donor recipients need to meet special criteria to be able to perform this procedure.

\section{METHODS}

This type of research is quantitative. The pre-time experiment aims to determine the effectiveness of the Apheresis method on the quality of blood products at the PMI UTD Surabaya City.

This study used a post test only control design. In this study design, there were two groups selected randomly. The untreated group is called the control group. 


\section{STRADA Jurnal Ilmiah Kesehatan}

DOI: $10.30994 /$ sjik.v9i2.511

ISSN: 2252-3847 (print); 2614-350X (online)

Vol.9 No.2 November 2020 Page. 1617-1621

At a predetermined time, the experimental group was given treatment. After the treatment was complete, measurements were taken of the two groups. If there is a significant difference between the experimental group and the control group, then the treatment given has a significant effect. The effect of treatment is (O1: O2) (Sugiyono, 2017).

The data were taken from the results of the examination of the quality of the platelet components by comparing the group from the normal blood draw and the blood sampling group using the apheresis method, the results of the quality test were analyzed to see if there were differences in the quality of the two groups.

The data analysis used is bivariate data analysis, which is an analysis that is carried out by more than two variables (Bambang 2016,181)

This analysis is used to test the effectiveness of the application of the Mc Nemar test on the fulfillment of apheresis platelet blood at UTD PMI Surabaya City. To determine the difference in the quality of apheretic platelet blood or voluntary blood donors using the Mc Nemar test.

\section{RESULT}

a. Quality of blood products by the Apheresis method

Table 4.5 Distribution of blood product quality by the Apheresis method at UTD PMI Surabaya City

\begin{tabular}{cccc}
\hline No. & Quality product & Frequency & Percentage \\
\hline 1 & Good & 50 & $100 \%$ \\
2 & Good Enough & 0 & 0 \\
\hline & TOTAL & 50 & $100 \%$ \\
\hline
\end{tabular}

Based on table 4.3, it can be seen that the quality of blood products carried out by the Apheresis method is a good criterion for all samples (100\%).

b. Quality of blood products that are not carried out by the Apheresis method

Table 4.6 Distribution of blood product quality that is not carried out by the Apheresis method at the PMI UTD Surabaya City

\begin{tabular}{cccc}
\hline No. & Quality product & Frequency & Percentage \\
\hline 1 & Good & 48 & $96 \%$ \\
2 & Good Enough & 2 & $4 \%$ \\
\hline & TOTAL & 50 & $100 \%$
\end{tabular}

Based on table 4.6, it can be seen that the quality of blood products that are not carried out by the Apheresis method is good criteria with a total of 48 samples (96), the criteria are not good with a total of 2 samples $(4 \%)$.

c. Cross tabulation The effectiveness of blood products that are used by the Apheresis method and those that are not used by the Apheresis method

Table 4.7 Cross distribution of the effectiveness of blood products using the Apheresis method and those not using the Apheresis method at UTD PMI Surabaya City

\begin{tabular}{cccccc}
\hline N & Blood & \multicolumn{2}{c}{ Apheresis } & \multicolumn{2}{c}{ Non Apheresis } \\
\cline { 2 - 6 } o & Componen & Frequency & Percentage(\%) & Frequency & Percentage(\%) \\
\hline 1 & Good & 50 & 100 & 48 & 96 \\
\hline
\end{tabular}




\section{STRADA Jurnal Ilmiah Kesehatan}

DOI: $10.30994 /$ sjik.v9i2.511

\begin{tabular}{|c|c|c|c|c|}
\hline \multirow{2}{*}{$\begin{array}{l}\text { Good Enough } \\
\text { Total }\end{array}$} & 0 & 0 & 2 & 4 \\
\hline & 50 & 100 & 50 & 100 \\
\hline \multicolumn{4}{|c|}{ MC Nemar Test } & 0,00 \\
\hline
\end{tabular}

Based on table 4.7, the cross distribution of the effectiveness of blood products by the Apheresis method is in the good criteria for 50 samples and the criteria for which the Apheresis method is not carried out, the criteria are good for 48 samples and 2 samples are not good criteria.

The results of the Mc Nemar test using SPSS obtained a $\mathrm{p}$ value of 0.000 . Because the $\mathrm{p}$ value $<0.05$, the Apheresis method is effective on product quality at UTD PMI Surabaya.

\section{DISCUSSION}

Based on the results of the MC Nemar effectiveness test with significant results $(\mathrm{P})$ value of $0.00<0.05$. So based on the research hypothesis it can be concluded that if the $\mathrm{P}$ Value $<0.05$ then $\mathrm{Ho}$ is rejected and $\mathrm{Ha}$ is accepted, which means that there is an effectiveness of the Apheresis method on the quality of blood products at UTD PMI Surabaya City.

Apheresis platelets come from 1 donor through the platelet pheresis process, in this process the donor will be connected to a blood cell separator machine that can separate each WB blood component, then the machine will spin the blood for several cycles according to the desired platelet count. On the Apheresis machine, there is a special sensor to identify the limit of plasma components containing platelets so that it can reduce the risk of the FNHTR reaction, contamination of bacteria, malaria, and CMV.

Based on previous studies, if the transfusion of random platelets contains 108 leukocytes, this increases the risk for leukosyte-mediated reactions. The advantage of Platelet Leukoreducet is that it can reduce the risk of alloimmunization so that it can reduce the risk of refractory. Reducing the risk of transfuse reactions, reducing the risk of intra-cellular viral transmission, lowering the plasma amount of platelet components (able et al, 2007).

Based on the researcher's opinion, other advantages obtained when performing TC Apheresis transfusions are less exposure from the donor to the recipient, lowering the risk of disease transmission through transfusion, reducing the risk of transfusion reactions, increasing patient response to platelet transfusion, extending the time interval between one transfusion and the next, lowers the risk of refractory thrombocytopenia, is able to provide platelet-matched products.

The effectiveness of the increase in platelet count after platelet transfusion can be influenced by various factors, including the result of differences in platelet dosage, source of platelets (apheresis or concentrated platelets), donor-recipient compatibility, and storage period of platelets as well as the presence of refractory properties to platelet transfusions (platelet refractoriness). . Each of these characteristics can influence the post-transfusion increase in platelet count. (Asri, 2019)

After doing the research for 5 months, the researchers concluded that giving Tc Apheresis is more effective than Tc Non Apheresis in patients who need a large number of platelet increases. 


\section{STRADA Jurnal Ilmiah Kesehatan}

DOI: $10.30994 /$ sjik.v9i2.511

ISSN: 2252-3847 (print); 2614-350X (online)

Vol.9 No.2 November 2020 Page. 1617-1621

\section{CONCLUSION}

The quality of blood products carried out by the Apheresis Method at UTD PMI Surabaya City shows that they have met the quality standards that have been tested from 50 blood samples. The quality of blood products that were not carried out by the Apheresis Method at UTD PMI Surabaya City showed that 2 blood samples did not match the standard, while 48 other blood samples met the standard. There is an effectiveness of the Apheresis method on the quality of blood products at UTD PMI Surabaya City. Based on the significant $\mathrm{p}$ value, namely $0.00<0.05$, according to the results of the Mc Nemar test, H0 is rejected. Ha is accepted

\section{REFERENCES}

Asri, Lisdiana. 2019. Analisis Corrected Count Increment (CCI) pada penderita post transfusi trombosit apheresis di RSUP Dr. Wahidin Sudirohusodo, Makassar, Indonesia. Intisari Sains Medis 2019, Volume 10, Number 2: 398-402

Dinas Kesehatan Provinsi Jawa Timur 2018, Profil Kesehatan Provinsi Jawa Timur 2012 Heriyanto, B ; 2016 Metode Penelitian Kuantitatif Surabaya : Perwira Media Nusantara Kementerian Kesehatan Republik Indonesia 2018. Profil Kesehatan Indonesia tahun 2017 Kementerian Kesehatan Republik Indonesia 2016. Tanya jawab tentang Donor Darah 2016 Kiswari Rukman. 2016. Hematologi dan transfusi. Semarang: Erlangga.

Saputra dan Setiawan 2014 Informasi Kesehatan Vol 8 No. 11

Fahrul Jaya Diputra 2017. Donor Darah.Media Indonesia.com

Pule, dkk 2015 Therapeutic Efficacy of Pletelet Transfusion in patien : an evaluation of Metods Transfusion 2014) : 766 - 775

EDQM, 2017 Guide tuthe Preparation, use on Quality Assurance of Blood Component ed. Directorate For the quality of medicines of healt care Of the council of Europe (E Dom) strass 60 orang, PP : 113 - 146, 2019 - 223, 269 - 310

Departemen Kesehatan 2015 : Donor darah hidup Sehat sambil beramal

IDAI, 2016 Pedoman Pelayanan Medis $2^{\text {nd }}$. Badan Penerbitan Ikatan Dokter Anak Indonesia, Jakarta PP : 3014 -317

Kementerian Kesehatan Republik Indonesia 2015, Peraturan Menteri Kesehatan Republik Indonesia Nomor 91 tahun 2015 tentang Standart Pelayanan Transfusi Darah Kementerian Kesehatan Republik Indonesia Jakarta

WHO 2015 Blood Safety and Ausilability who.int/Media Centre/Factsheets PP : 1-8 Henrich J 2018 Blood Supply : Availability of Blood Healt education and Human Service Devision Report, United States

AABB.2015, American Red Cross, American`s Blood Center, Armed Services Blood Program : Circular Of Information For The Use Of Human Blood And Blood Component, $P: 1-47$ 